\title{
MORAL ACTION, COLLECTIVE ACTION, AND RESPONSIBILITY FOR CLIMATE CHANGE
}

\author{
James CONNELLY*
}

\begin{abstract}
Through an examination of some of the moral and political difficulties impeding people acting individually and collectively in pursuit of reduced carbon emissions, this article addresses the ways in which the government can and should encourage citizens to modify their behaviour and become good environmental citizens. The article touches on issues of rational choice and collective (ir)rationality, considers the individual moral response to these and the extent to which the government can act to eliminate or reduce the threat of inertia caused by collective action problems. Although the article is primarily focussed on the responsibilities of individuals in general, it also considers their role and views as citizens of states and supranational organisations such as the European Union. It also briefly addresses the problem of climate change as a "viciously nested" collective action problem, repeated at all political levels, from individuals to states to the European Union to international organisations, treaties and accords.
\end{abstract}

Keywords: Climate change, collective action, European Union, individual responsibility, ethics.

\section{İKLIM DEĞişiKLLIĞí İÇIN AHLAKİ EYLEM, KOLEKTIF EYLEM VE SORUMLULUK}

$\ddot{O} z$

Bu makale, karbon salımlarını düşürme uğraşında insanların tek başına ve bir arada hareket etmelerini sekteye uğratan ahlaki ve siyasi zorluklarl inceleyerek, hükümetin vatandaşlarını davranışlarını değiştirmeye ve iyi çevresel vatandaşlara dönüşmeye teşvik edebileceği ve etmesi gereken yollar ele almaktadır. Makale, rasyonel seçim ve kolektif (ir)rasyonellik hususlarına değinmekte; bu hususlara verilen bireysel ahlaki yanıtı ve hükümetin kolektif eylem sorunlarından kaynaklanan atalet tehlikesini ne derecede bertaraf

* Emeritus Professor of Political Thought, University of Hull, e-mail: J.M.Connelly@associate.hull.ac.uk. 
edebilecĕ̆ini veya azaltabileceğini değerlendirmektedir. Makale, esasen, bireylerin genel itibariyle sorumluluklarına yoğunlaşsa da bireylerin devletlerin ve Avrupa Birliği gibi ulusüstü kurumların vatandaşlarl olarak da rollerini ve görüşlerini dikkate almaktadır. Makale ayrıca iklim değişikliği sorununu bireylerden devletlere, Avrupa Birliği'nden uluslararası organizasyonlara, antlaşmalara ve mutabakatlara dek tüm siyasi düzeylerde tekrar eden "meşumca iç içe geçmiş" bir sorun olarak kısaca ele almaktadır.

Anahtar Kelimeler: İklim değişikliği, kolektif eylem, Avrupa Birliği, bireysel sorumluluk, etik.

\section{Introduction}

This article addresses the issue of the role of the individual and government in reducing climate change emissions. The primary focus is a consideration of the division of responsibility between state and individual and the limits of what one can reasonably expect of people making individual moral choices. It asserts that each individual has an absolute moral responsibility for their individual actions and hence a responsibility to arrange their choices so as to limit and reduce their carbon emissions. ${ }^{1}$ However, it recognises that practical and motivational issues intervene and that the government needs to step in to encourage, nudge, or require certain actions.

This article is primarily concerned with the responsibilities of those in the developed world, principally in the European Union (EU) and USA. This is not because people in other parts of the world do not also have responsibilities, but because those in the developed world have greater responsibilities as a direct consequence of the greater harm they have caused in the past and are causing in the present. If asked why the current generation should be held responsible for the actions of their forefathers, the answer is that they have benefitted (and continue to benefit) from those actions and hence cannot disown them. There is no convenient cut-off between past and present; the lifestyle, patterns of consumption and production in the USA or Western Europe are what they are because of their industrial past. Individuals and governments are all responsible. All should share the burden and agree what share of the burden applies to them. The issue is one of proportionality, and, proportionally speaking, it is those in the industrialised countries who have responsibility to act first and to assume the greatest burden. This is not only because they have benefitted in the past and still do, but also because through the accumulated effects of that benefit

\footnotetext{
${ }^{1}$ Brooks $(2016,2020)$, while not dissenting from this claim, argues (rightly) that many of our favoured ways of measuring responsibility and taking appropriate action (e.g. by measuring our "carbon footprint") are deeply flawed and need serious reassessment if not replacement.
} 
they possess the greatest resources to address the problem. To argue otherwise is to argue that those who have benefited the least (or suffered) from the effects of climate change, and who have fewest resources to address the problem, should bear a greater proportional burden than those who have benefited the most. This would be both absurd and morally grotesque.

The article proceeds by considering the dilemma of individual moral responsibility, linking this to the paradox that individual action, although its immediately palpable effects appear to shrink to a vanishing point, is nonetheless both necessary and valuable. Following these ethical inquiries, the article outlines existing attitudes towards the environment on the part of EU and US citizens and links this with another paradox, that is, that although citizens will often state that they require more information, in fact rational ignorance is a reasonable stratagem and simply providing more information often pointless and sometimes counter-productive.

\section{The Dilemma of Individual Moral Responsibility}

The standard understanding of moral action and responsibility is mainly about individual and easily identifiable harms which are local in both space and time. However, the causes and effects of climate change (and those who cause and those who are affected) are distributed across the globe and dispersed in time. Further, there is serious time dislocation between cause and effect: it takes a significant amount of time for actions to be converted into observable effects on the climate. By the time see the effects are seen, it is already late, and if one is pessimistic, too late.

Climate change is an example of an unintended consequence caused by people and organisations spread out in time and space and experienced differently in time and space. In some ways it would be convenient to be able to identify a single culprit to blame and charge with the task of putting the world right. To some extent this is done when people blame a country such as the USA for its vast per capita over-contribution to climate change emissions. But this is neither serious politics nor ethics. One needs to look a little deeper and consider the extent to which all governments in the developed world and their citizens are complicit in climate change and hence, through that causal responsibility, share a moral responsibility for rectifying it.

There is a familiar underlying principle here: it is normally assumed that if a person caused some harm, he/she has a responsibility to make reparations or to put it right - in other words, we typically assign a strong relationship between moral and causal responsibility. In particular, this implies that those who have done most harm have the greatest responsibilities, whether they are individuals, corporations, or government. And in so far as the people, corporations, and government in the developed world have caused most harm, they have a 
corresponding moral responsibility to solve the problem. Peter Singer, thus, expressed:

as far as the atmosphere is concerned, the developed nations broke it. If we believe that people should contribute to fixing something in proportion to their responsibility for breaking it, then the developed nations owe it to the rest of the world to fix the problem with the atmosphere (Singer, 2004: 33-4).

However, the matter, whilst complex at any level, seems to generate further complexities at the level of individual action. As James Garvey points out:

It is unclear ... that any particular action of mine is causally responsible for any future harm. All the little things that I do today ... might amount to nothing more than a negligible amount of damage to the atmosphere. It is almost as though I am jointly responsible, with a million other people, for a billion little actions, in a trillion little moments. Each act is nothing in itself, each person does not obviously wrong, but together the results are catastrophic (Garvey, 2008: 61).

Morally speaking (although not necessarily politically or practically speaking), morally-required action is not contingent upon the actions of others. That is, if someone has done harm, they have an individual responsibility for the harm that they have caused simply because they caused it, independently of the actions or inactions of others and of the size of their contribution to the aggregate harm. This raises two questions. The first is whether it makes sense to say that certain small actions which are not obviously harmful in themselves are nonetheless to be counted as morally wrong because of the aggregate consequences of many doing likewise. The second is how the relation between one's acting (or not) and other people's acting (or not) should be considered.

Perhaps the prime issue in considering collective action problems is that although someone may have contributed their share to collective harm, that share is so small by comparison with the whole that there seems little point in refraining from emissions unless others (or a significant number of them) do so also. To make the point personal, one might ask whether we regard any action of our own pointless if its positive effects were immediately cancelled by the negative effects of the actions of others. This is a legitimate worry even if the action is a morally required action; if one is a consequentialist, the fact that one's act has no beneficial consequences is simply to say that it is not morally required. Either way: why bother?

There are two responses to this. The first is that one is responsible for one's own actions, not those of others, and it is no excuse for my failing to act morally that others might also have failed. Secondly, for one to act properly might be a condition for the successful action of others (or for the commission of a jointly successful action comprising one's action and those other actions 
aggregated with it forming, as it were, a single jointly commissioned action). In other words, one's action might make other actions possible, and, by doing so, lead to overall beneficial effects. Not to act, by contrast, pre-empts the situation by withdrawing a necessary condition for the success of these other actions. This account applies independently of whether one is a consequentialist or a Kantian in ethics. One's deed might be cancelled by another; equally it might add to another to make something more than either or both as a simple aggregate. Here, one needs to see actions as cumulative and complementary, not as isolated and separate but as contributory to a wider whole. To conclude the point: not to act might undermine successful action by others, and is therefore wrong; and to refuse to act unless others do so as well is morally wrong because it is morally contradictory in a vicious, hypocritical and selfregarding way. The contradiction consists in ignoring the moral demands made on us while at the same time making moral demands of others. Of course one might have a moral duty to encourage others to act properly too, but one's words and deeds will have no moral (and certainly no persuasive) traction if one does not do oneself what one should. Even if one is doing the right thing there is no guarantee that others will follow; but if one is not, there is every likelihood that one will be justifiably accused of hypocrisy and for that reason fail to persuade. Garvey (2008) makes the point in a telling way, and it is important that he is making it against the consequentialist - who is more likely than anyone to retreat to the position of refusing to take action unless everyone does, likewise in order to attain the aggregate consequences:

The first thing a consequentialist should notice, against the claim that individual choices cannot matter much, is that nothing else about you stands a chance of making a moral difference at all. If anything matters, it's all those little choices. The rejoinder shows up all over the place, just about anywhere you hear the claim that nothing a single person can do could possibly make a difference. The little effects are the only effects you'll ever have. The only chance you have of making a moral difference consists in the individual choices you make (Garvey, 2008: 150).

However, despite the undoubted truth of these remarks and of the assertion of non-transferable moral responsibility, we can still sense the shadow of the collective action problem looming behind us. Let us consider two dimensions of this. The first relates to the moral status of small actions and the second to the problem of overcoming collective action problems and the role of government in this.

The problem comprises the vastness of the effect, the tininess of individual contributions, together with the phenomenon of convergent causation. Climate change depends on a variety of conditions which converge. Each condition is necessary but not sufficient; but together they are sufficient to produce the effect. This leads to three closely related problems. The first is that of the moral 
nature of an act which is not in itself a cause of danger but only becomes so when aggregated with many other thousands of acts of like kind. The second is the sort of moral responsibility we have for acts of this sort and whether we have a duty to refrain from committing them. Thirdly, the issue of how (if at all) we are able to persuade someone who is not otherwise (morally autonomously) inclined to act that they ought to do so. Flowing from these considerations are the themes of the rest of the article, that is, what particular means a society employs to induce people to behave in an appropriate manner to the long term securing of a low carbon future.

\section{Why Do Deeds Too Small to Make a Difference Make a Difference?}

Is it immoral to act in a certain way if the adverse consequences of doing so are a collectively created whole in which my action is not only a tiny part, but would not be considered morally wrong independently of the whole? The dispersal of a small amount of effluent in a river, for instance, does not create a problem of pollution; but the collective dispersal of an amount of effluent beyond its carrying capacity does. Is my individual contribution wrong in itself or does it only become wrong when aggregated? Can individual actions acquire the property of wrongness in this way, or should we say that there is a collective wrong which is not composed of a large number of individually wrong actions? Although it is not clear what the answer is, it nonetheless matters because the issue has a practical bearing. This is because it makes a difference, as a matter of moral persuasion whether we are able to say an individual action is morally wrong (and to be judged as such, no matter how seemingly insignificant) or whether we do not regard them as morally wrong but merely part of a collective whole which is the unintended outcome of individually blameless actions.

How shall we decide this? Which model shall we follow? Compare the case of the gradual diminution of respect and good manners that might occur as a result of individual acts of rudeness. The difference, however, is that an individual act of rudeness is a clear act of rudeness and to be judged accordingly, independently of its aggregated consequences. It is not obvious that carbon emissions are in the same sense wrong in themselves; but if they are not, how can we persuade others not to do something which is not in itself morally wrong or only wrong in respect of the consequences of myself and many others doing it? The answer at this point, it seems to me, is that we have to take recourse in the idea that we each of us have a share of the planet's resources and that to over-consume our share is morally wrong, whether or not so doing has any immediate and observable effect on the lives of others or not. Greed, in this sense, is to take more than my fair share, to take what rightly belongs to others, whether they are currently claiming it or not. Here what is being taken is access to environmental resources of all types, including carbon sinks. This leads in the direction of individual responsibility and, in climate 
change terms, to the calculation of carbon emissions on a per capita basis. And our conclusion is that there is always a moral responsibility to act within the limits of our assigned ecological footprint whether or not others do so, or not. We also always have an obligation to persuade others to follow suit, and this implies not a retreat to what might become individual moral or environmental priggishness but rather a duty of persuasion, example and activism.

\section{What Citizens Think and Do: An Environmental Paradox?}

As an introduction to the themes of collective action to be addressed, one should first consider how people think in practice about environmental issues. Is it fair to say, with Iain McLean (2008: 189), that "People are willing to do (only) things that seem cheap, and things whose cost appears to fall on other people"? His point is that "the environment is generally a medium salience issue ...". 2 Let us briefly consider the views of EU citizens on climate change over the past ten or so years.

Over the past decade or so the EU has conducted regular special Eurobarometer surveys on attitudes toward the environment and climate change, published in 2008, 2014 and 2020. The following answers are indicative generalisations derived from three Eurobarometer $(2008 ; 2014 ; 2020)$ surveys relating to citizens' sense of individual moral and causal responsibility. Similar surveys have been conducted in many other countries such as the UK and the USA and they reveal broadly similar responses. The later surveys showed that there had been some decline in the sense of personal concern and responsibility for climate change. Given the unfolding economic crisis, this is perhaps not surprising. Over half of EU citizens feel "very well or fairly well informed about different aspects of climate change," both causes and consequences (Eurobarometer, 2008: 18). However, over four in ten either feel "not very well, or not at all, informed" (Eurobarometer, 2008: 18). Those who considered "climate change to be a very serious problem" felt better informed about its different causes and effects than "those who do not consider it to be a serious problem" (Eurobarometer, 2008: 18).

As for personal contributions, a majority confirm that they "have taken some kind of action" (Eurobarometer, 2008: 22). Taking action is correlated positively with education and information: it is much more widespread among those who feel well-informed about climate change. Again, those who thought climate change to be "a very serious problem" were "considerably more likely to have taken personal action" than those who disagreed (Eurobarometer, 2008: 27).

\footnotetext{
${ }^{2}$ McLean's argument is complementary to the one developed in this article, although with a greater emphasis on rational and public choice arguments.
} 
What about perceptions of responsibility? "Europeans clearly think that not enough is done to fight climate change" (Eurobarometer, 2008: 40). Around three-quarters of respondents said that corporations and industry were not doing enough; around two-thirds that citizens themselves are not doing enough; around two-thirds that their national government was not doing enough; approaching two-thirds that the EU was not doing enough (Eurobarometer, 2008: 40). Absolute majorities in all countries believed that citizens were not doing enough; an opinion was shared by two-thirds of Europeans (Eurobarometer, 2008: 43).

What do citizens tell us they are doing? There are three broad categories of activity. First, the most common actions citizens have taken are those "that require the least personal and financial effort", such as "waste separation and reducing the consumption of energy, water and disposable items" (Eurobarometer, 2008: 62). Secondly, there are actions requiring more individual effort and are typically without clear cost-benefits (Eurobarometer, 2008: 62). These include environmentally friendly transport, using seasonal and local products, "reducing car use and purchasing a more environmentally friendly car" (Eurobarometer, 2008: 62). Thirdly, there are actions that require a stronger personal commitment and which tend to be expensive: for example, "avoiding short-haul flights, switching to a green energy supplier and installing equipment for generating renewable energy at home" (Eurobarometer, 2008: $62)$.

Are citizens ready to pay for action against climate change? It all depends: less than half said that "they would be ready to pay between $1 \%$ and $30 \%$ more for green energy"; a third "would not be willing to pay more" and a quarter had no opinion (Eurobarometer, 2008: 68). Generally speaking, "the main reason for taking action against climate change" is a sense of doing one's bit, and a belief that "if everybody changed their behaviour it would make a real difference" (Eurobarometer, 2008: 72). The predominant reason for not taking action is the view "that governments, companies and industries" (rather than citizens) "should change their behaviour" (approaching 50\%) (Eurobarometer 2014: 25). In the second place, around a third of citizens confirmed that "they would like to take action but do not know what they could actually do to contribute to fighting climate change" (Eurobarometer, 2008: 76). Around a quarter felt that changing one's behaviour would not have any actual impact on climate change and around 10-20\% believe that taking action "would be too expensive" (Eurobarometer, 2008: 76). These figures are reasonably constant over time, as the Eurobarometer surveys from 2008 to 2020 clearly show.

Overall, although more than half of Europeans "feel informed about the causes" and "the consequences of climate change" and "the ways of fighting it, the proportion of citizens that feel poorly informed remains significant" 
(Eurobarometer, 2008: 80). A clear majority confirmed that they have taken some kind of action to fight climate change - but this is much more prevalent amongst those who feel informed about climate change rather than those who feel poorly informed (Eurobarometer, 2008: 27). Although this might sound almost tautological, it is not, if one takes "into account that lacking information is mentioned as an important reason for not taking action against climate change" (Eurobarometer, 2008: 80). The main reason given for citizens not taking action is that they think that governments, companies and industries should change their behaviour (Eurobarometer, 2008: 46-47). In so far as they did act, "Europeans mainly undertook actions requiring relatively little personal or financial effort, like waste separation and reducing consumption of energy, water and disposable items" (Eurobarometer, 2008: 80). A good proportion, however, "admits that the cost-benefits of taking these actions are their major motivation for actually doing so" (Eurobarometer, 2008: 80). The results also show that even though Europeans in general are "highly concerned about climate change and clearly willing to take action against it", they frequently "lack knowledge and information about how to do it" (Eurobarometer, 2008: $80)$.

Surveys in America show a similar mixed picture and range of responses. One finds not only that people prefer to do what is cheap and easy but also that even those self-identifying as environmentalists, are rarely willing to bear the full burden of what this requires in practice. This is the paradox identified by Dale Jamieson (2006: 97): most of the Americans surveyed regard themselves as environmentalists; they believe that climate change is bad, and say they are willing to pay to mitigate it (Humphrey, 2009). However, when asked to consider specific policies with definite costs their support weakens immediately (Jamieson, 2006: 97-102). In other words, they will be the ends but not the means; especially as the ends are broad and general, and temporally and spatially non-specific, and the means are immediate and localised in space and time. They will do the general good but not the specific means to attaining it.

As Mathew Humphrey (2009: 153) notes, this paradox is universal: similar findings hold for the UK where what McLean describes as "cheap talk environmentalism" (McLean, 2008: 189) is prevalent. Some researchers report that "that there is a 'contradiction' in people's attitudes to climate change, they express concern but then oppose policies designed to mitigate its effects" (Humphrey, 2009: 148). Again, a UK survey reported that about two thirds of respondents thought climate change is "best managed through behavioural change, but only 8 per cent thought that responsibility for this" lies with "individuals and families" (Humphrey, 2009: 148). These, and many similar reports, substantiate the paradox identified by Jamieson (2006). 
Overall, there is clearly a stronger wish to blame others than to assume individual responsibility. One remedy (typically propounded by the European Union), is to increase the flow of information to citizens in the belief that it is lack of information that causes the problem and that increased provision of information will solve it. Although information might be necessary, it is certainly not sufficient; and even where necessary, there is still an issue of what sort of information and how it is to be presented. Information per se can be an overrated commodity.

\section{The Problem with Information: Rational Ignorance and Rational Irrationality}

A typical assumption is that if people know about the problems, about the solutions and about what they, governments, organisations and industry can do, they will become more involved and seek to promote action. This is probably an over-optimistic assumption. At the least, one might discover that information is necessary but by no means a sufficient condition for action and that, further, a proliferation of information might very well have adverse effects. Information overload merely increases the problem and this fact indicates that one should be careful before concluding that the answer is "first provide more information".

So, why this is a problem? The answer lies in two phrases: rational ignorance and rational irrationality. First, the private cost of being mistaken or ignorant about public policy is for most, most of the time, zero (Humphrey, 2009). Secondly, if by the term irrationality one means holding strong views without good reason, this can be rational when they are also costless. By costless here is meant immediately and personally: of course the aggregate or cumulative effects are not costless to society as a whole.

The gathering of information costs time and money and effort and there are further costs in processing and understanding it. People are most prepared to spend time and money on information when it is directly relevant to their interests and where possession of the information might make a perceptible difference to their lives, or where their actions might perceptibly make a difference to a collective or political situation. The obvious example is, of course, becoming an informed voter. Is it rational to spend time and effort gathering and mastering information when, in an election "with millions of voters, the personal benefits of learning more about policy are negligible, because one vote is so unlikely to change the outcome" (Caplan, 2006).

Climate change also shares these characteristics with voting. That is, a salient feature of the problem is precisely that there might seem little point on the part of an individual actor either to inform him or herself or to ensure that his or her understanding was rational as well as well informed. "Rationality" and being "well informed" are two separate not necessarily mutually 
reinforcing items because many well informed people, as we know, can nonetheless be quite irrational. Information per se does not give one judgement and judgement tends to be developed when one has real choices to make with palpable individual consequences.

The notion of "rational irrationality" is an idea associated with the work of Bryan Caplan (2007). The focus here is solely on his analysis of the cost of error for the average citizen. Caplan (2007: 123) argues that the problem of rational ignorance has been overstated. It cannot explain why people gravitate toward false beliefs (rather than agnosticism) and it cannot explain why people who are objectively ignorant of a subject are so confident in their judgments (Caplan 2006, 2007). Caplan's $(2006,2007)$ view is that these are symptoms of irrationality. In politics, some beliefs are more emotionally appealing than others. There is a temptation to relax normal intellectual standards and insulate favoured beliefs from criticism (Caplan, 2006). In his view, irrationality, like ignorance, is sensitive to price, and false beliefs about politics and religion are cheap (Caplan, 2007: 114-141).

Caplan's claim, in summary, is that it is often virtually cost-free for an individual person to retain an already existing belief, whether it is well-founded or not. His notion of "rational irrationality" is that the motivation for holding a belief is the cost of believing it, not its truth: if it is cheap to hold a certain belief, it is rational to believe it, irrespective of its truth or falsity (Caplan, 2007: 114-141). Caplan argues that:

since delusional political beliefs are free, the voter consumes until he reaches his "satiation point," believing whatever makes him feel best. When a person puts on his voting hat, he does not have to give up practical efficacy in exchange for self-image, because he has no practical efficacy to give up in the first place.

Caplan's (2007) point is simply that if the costs of being wrong are low or zero, there is no incentive not to be wrong. This goes together with the point that one is then in a position to believe what one believes not for good or rational reasons but on the basis of how one would like to think the world to be (whether this is good or bad). People can have strong views for bad reasons. There are, in other words, good reasons for bad reasoning because the cost of being wrong is low or zero. If this is added to the point about rational ignorance one can instantly see why the answer to the problem of public understanding and participation is not simply the provision of more information. The syllogism is wrong. It runs: the public does not know if they knew they would act, so we must ensure that they know. Rational ignorance explains why people might choose not to bear the costs of knowing; rational irrationality shows why they might freely choose the irrational in certain cases. 
Humphrey (2009: 156) suggests that this explains why rational ignorance can also lead to "political posturing" in environmental policy making. Citing McLean (2007), he also suggests that it helps explain that in the abstract, people are happy to demand that "something must be done" but then shy away from the prospect of paying the obvious costs of such action (Humphrey, 2009: 150). In other words:

People are prepared to hold strong views on environmental matters for as long as those views are costless. When, however, these views cease to be costless, the changing payoffs are likely to lead to revised views. When people are asked specific questions about how much tax they would pay to mitigate climate change, or whether they would give up their car, the costs of climate change abatement become obvious. Even though one could at this stage give a dishonest answer to maintain consistency with the abstract view, people seem more likely to report contradictory preferences: thus the paradox (Humphrey, 2009: 160).

This might all sound rather negative; it is not intended to be: it is merely intended as a warning against expecting an increased flow of information, or enhanced rights of access to information, to be more than a necessary condition for enhanced environmental citizenship. The active will use it and seek it out; the inactive will continue inactive because their inactivity is not primarily a response to the unavailability of information in the first place. Voters will not necessarily wish to be well informed and rational, whatever the importance of the issue. What this shows is not only that simply feeding more information to voters and citizens is not enough, but also that if one wishes them to be more rationally informed one has to show them the consequences of their actions for themselves. Unfortunately this is difficult where one is dealing with convergent causation: morally they have responsibilities, but practically they have no incentive to consider their options morally or assess their contribution to a wider cause.

\section{Breaking through: the role of government}

Bringing this together, how can we address the collective action problem and the problem of rational ignorance, without constant resort to totalitarian interference in the lives of individuals? This article focuses primarily on individual responsibility, rather than governmental or intergovernmental action. But it is important to note that the background setting for the problem is not only that the problem of addressing climate change is not only a classic collective action problem, it is a viciously nested collection action problem. What this means is that the problem arises at the level of individual action, as previously described; it then re-emerges at many different levels: at the level of social, political and economic organisations; at the level of governments; at the level of the EU, which is an international actor in its own right and therefore to 
some degree solves the problem within its own membership - although recalcitrant members such as Poland and Hungary cause it difficulty. But internationally, the EU cannot carry the burden alone, and the formation of an adequate climate change regime requires the full participation of the USA (which has been absent for the past four years, but might return under the Biden presidency in 2021) and strong emerging economies such as China, Brazil and India. Hence the individual collective action problem relating to action on climate change is nested inside the organisational, inside the regional, inside the national, inside the international, and so on. This is one among many reasons why it is so difficult to secure solid and reliable action in each of these political arenas.

As stated, the focus of this article is individual responsibility. However, it should also be noted that according to Eurobarometer and other research, individual citizens in the EU, US and elsewhere, are perfectly aware that addressing climate change is a shared responsibility between citizens, governments, business and labour organisations, and international organisations, regimes and treaties. The 2020 Eurobarometer shows clearly that citizens are keen to protect the environment but that:

responsibility should be shared by big companies and industry, national governments and the EU, as well as citizens themselves. [They] considered that the most effective ways of tackling environmental problems are "changing the way we consume" and "changing the way we produce and trade (European Commission, 2020).

This shows a clear understanding on the part of citizens that while they have responsibilities, some responsibilities have to be shared, and others are primarily the responsibility of large corporations or governments or states or international organisations.

In relation to individual action, one might begin by asking why government is necessary. One answer is that there will always be certain things which are straightforward matters of legal prohibition or requirement and the government will always be required to provide for these. In respect of the argument of this article, the answer is that individuals need not only the moral sense that they should do the right thing, but the guarantee that others are also doing the right thing. This is especially true where their part in the whole is causally negligible. Morally nothing changes, but motivationally something does, in the absence of a sense of solidarity. This raises the question of whether solidarity can be created by governments and whether governments can help promote individual environmentally sensitive moral action. The answer argued for here is a qualified yes on both counts. 
We all possess velleities, that is, we all have a number of desires too small to be acted upon. Environmental desires are often velleities: people are typically not opposed to environmentally sensitive activity, but their desire is too weak to stir them to action. In such cases we could deploy rewards or incentives for good actions and punishment for bad actions. But this approach has its limitations because people really need to stimulate internal motivation. Here, one should ask how one might hinder the hindrances to environmentally sensitive action.

Generally, people have to be induced to act in certain ways; for example, by making it easier to do certain things (e.g. recycling) which otherwise would not be done. In this we are looking to convert velleities into virtues by removing hindrances to action, thereby inclining citizens towards action. The claim is that, through action, participation and engagement, people become inducted into a way of living and doing which settles into a virtuous groove. Initially, it does not matter what the motive was; the point is that actions, having been embarked upon, gradually become the focus of reflection and thought. This can lead to other environmentally virtuous actions; in this way it is similar to the use of incentives to the same end: but the latter are not necessarily internalised. Environmental virtues can be encouraged, but this is not straightforward and relies on a range of responses to people's circumstances and appreciation of their already existing dispositions and motivations (Connelly, 2006: 69). However, against the sceptic or cynic who asserts that people will never rise above their selfish inclinations, there are good reasons to argue that success is achievable. After all, if people were always already textbook specimens of the self-interested utility maximiser presupposed by rational choice literature, it would be impossible to account for the levels of voluntary environmental activity we already observe around us (Connelly, 2006: 69). What is required, then, is to build on and develop this predisposition to environmental virtue so that it reaches those who do not yet recognise or act on it (Connelly, 2006: 689).

A complementary, and primarily practical, approach has recently been developed and popularised by the authors of Nudge (Sunstein and Thaler, 2009). What are its main features? The starting point is that one should identify the operative choice architecture governing any act of choice. Neutral design is impossible, and seemingly arbitrary decisions are of enormous importance. Choice architecture is defined as a structure designed by a choice architect to improve the quality of decisions. Sunstein and Thaler (2009: 5) do not regard this as being an inappropriate governmental imposition: they describe their position as "libertarian paternalism". By this, they mean a weak and nonintrusive type of paternalism which nudges people towards certain choices through the design of choice architecture, but which does not prevent people making any choices within the law they wish (Sunstein and Thaler, 2009: 5). They regard it as an approach to governance which helps people make choices 
that improve their lives, without infringing on the liberty of others (Sunstein and Thaler, 2009: 14). Appropriately designed choice architecture nudges people in the right direction without determining their actions: hence the notion of the nudge.

This is where the notion of analysing and manipulating the architecture of choice comes in. Some people will be on the verge of rational persuasion and moral responsibility and need a nudge; others might be actively hostile - and here, more information and overt moral pressure or persuasion will have no effect. In that case people design the choice architecture in such a way as to influence their behaviour irrespective of their immediate rational assessment of that behaviour. Of course, at the extreme they simply invoke the authority of the law; but within that they have many possibilities and they largely consist in adjusting and modifying the choice architecture in such a way as to lead (but not coerce) people to do one thing rather than another. However, as Tammy Boyce from the King's Fund observed, there is a danger that we are faced with short term solutions which have no long term effect (Lakhani, 2008). He further remarked: "We need to move away from short-term, politically motivated initiatives such as the 'nudging people' idea, which are not based on any good evidence and do not help people make long-term behaviour changes" (Lakhani, 2008). ${ }^{3}$

The conclusion, in line with what is argued above, is that we cannot guarantee the long term effect, but that if we encourage appropriate action there is a reasonable chance that both individually and collectively this can become not only habitual but also virtuous in nature. Overall, it is reasonable to conclude that the "nudge" only works where there is a pre-existing velleity and that the twofold task is to develop velleities and then to tip them into action.

\section{Conclusion}

This article has tried to show that, it is possible to insist on both the absolute moral responsibility of every individual for their actions. It has also maintained that, despite the difficulties in maintaining motivation in climate change action, citizens should act dutifully in respect of the environment. Secondly, that citizens can and will act dutifully and are more inclined to do so where they see the point of such action with a sense of solidarity arising from others acting in the same way. Finally, it has been suggested that citizens can be helped by all levels of government in doing this. One (but not the only) example of such help comes from the help that the government can give in nudging people into actualizing their latent preferences or velleities.

\footnotetext{
3 For a fuller discussion of "nudge", in the context of environmental citizenship, see Connelly (2014); for a discussion of nudging as an environmental policy instrument, see Evans et. al (2017).
} 


\section{References:}

Brooks, T. (2016) "How Not to Save the Planet", Ethics, Policy \& Environment, 19(2): 119-35.

Brooks, T. (2020) Climate Change Ethics for an Endangered World, (London: Routledge).

Caplan, B. (2006) "The Myth of the Rational Voter", Cato Unbound, 5 November 2006, <https://www.cato-unbound.org/2006/11/05/bryancaplan/myth-rational-voter>, (17 December 2020).

Caplan, B. (2007) The Myth of the Rational Voter: Why Democracies Choose Bad Policies, (Princeton: Princeton University Press).

Connelly, J. (2006) "The Virtues of Environmental Citizenship", in A. Dobson and D. Bell (eds), Environmental Citizenship, (MIT Press).

Connelly, J. (2014) "Idealist social philosophy, character and environmental virtues", in T. Brooks (ed.), Ethical Citizenship: British Idealism and the Politics of Recognition, (London: Palgrave Macmillan), pp. 224-44.

Eurobarometer (2008) (Special) "Attitudes of European citizens towards Climate Change", September 2008, No. 300, <https://ec.europa.eu/comm frontoffice/publicopinion/archives/ebs/ebs_300_full_en.pdf $>$, (17 December 2020).

Eurobarometer (2014) (Special) "Climate Change", March 2014, No. 409, $<$ https://ec.europa.eu/commfrontoffice/publicopinion/archives/ebs/ebs_409_ en.pdf>, (17 December 2020).

Eurobarometer (2020) (Special) "Attitudes of European citizens towards Climate Change", No. 501, <https://ec.europa.eu/commfrontoffice/ publicopinion/index.cfm/Survey/getSurveyDetail/instruments/SPECIAL/sur veyKy/2257>, (17 December 2020).

European Commission (2020) Press release: "New Eurobarometer Survey: Protecting the environment and climate is important for over $90 \%$ of European citizens", 3 March 2020, <https://ec.europa.eu/comm frontoffice/publicopinion/index.cfm/survey/getSurveydetail/instruments/spe cial/surveyky/2257>, (17 December 2020).

Evans, N., Eickers, S., Geene, L., Todorovic, M., and Villmow, A. (2017) "Green Nudging: A discussion and preliminary evaluation of nudging as an environmental policy instrument", FFU-Report 01-2017, Forschungszentrum für Umweltpolitik Freie Universität Berlin, Berlin.

Garvey, J. (2008) The Ethics of Climate Change, (London: Continuum).

Humphrey, M. (2009) "Rational Irrationality and Simulation in Environmental Politics: The Example of Climate Change", Government and Opposition, 44(2): 146-66. 
Jamieson, D. (2006) “An American Paradox”, Climatic Change, (77): 97-102.

Lakhani, N. (2008) "Unhealthy Lifestyles Here to Stay, In Spite of Costly Campaigns", The Independent, 7 December, <http://www.independent. co.uk/life-style/health-and-wellbeing/health-news/unhealthy-lifestyles-hereto-stay-in-spite-of-costly-campaigns-1055693.html.>, (26 November 2020).

McLean, I. (2008) "Climate change and UK politics, from Brynle Williams to Sir Nicholas Stern”, The Political Quarterly, 79(2): 184-93.

Singer, P. (2004) One World, (London: Yale University Press).

Sunstein, C. and Thaler, R. (2009) Nudge: Improving Decisions about Health, Wealth, and Happiness, (London: Penguin). 